\title{
North Atlantic Oscillation seesaw effect in leaf morphological records from dwarf birch shrubs in Greenland and Finland
}

\author{
Fabian E.Z. Ercan' ${ }^{1}$ Daan Blok², Stef Weijers ${ }^{3}$, Astrid Odé1 \& Friederike Wagner-Cremer ${ }^{1}$ \\ 'Palaeoecology, Department of Physical Geography, Utrecht University, Utrecht, The Netherlands; \\ 2Dutch Research Council, Den Haag, The Netherlands; ${ }^{3}$ Department of Geography, University of Bonn, Bonn, Germany
}

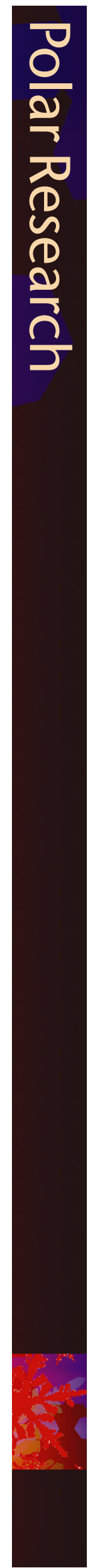

\section{Keywords \\ Palaeoecology; Betula nana; epidermal cell morphology; climate; Arctic; herbarium}

\section{Correspondence}

Fabian E.Z. Ercan, Palaeoecology, University, Princetonlaan 8a, 3584 CB Utrecht, The Netherlands. E-mail: fabianercan@gmail.com

Abbreviations
AM: April, May
CA: cell area
CC: cell circumference
FMA: February, March, April
GDD: growing degree days
MJJ: May, June, July
NAO: North Atlantic Oscillation
NDJF: November, December, January,
February
SLP: sea-level pressure
UI: undulation index
Greenland and vice versa. Increased knowledge of the UI response to climate may contribute to understanding ecological properties of key Arctic species,

\section{Introduction}

Cold season (October-May) warming in the Arctic is nearly three times stronger than in the remaining Northern hemisphere and is accompanied by a lengthening of the growing season through the advanced onset of spring (Box et al. 2019; Meredith et al. 2019; Bintanja et al. 2020). The main primary production in (sub-)Arctic tundra ecosystems is provided by typical low-growing shrubs, including Betula, Cassiope, Salix and Vaccinium species (Walker et al. 2005). Generally, Arctic vegetation is temperature limited by harsh winter conditions and short and relatively cold growing seasons. A continuation of rapid warming during the cold season has the potential to release this temperature limitation, leading to structural alterations of the habitat through changes in local snow cover, hydrology, frost protection, permafrost dynamics and nutrient availability (Box et al. 2019; Meredith et al. 2019; Steinthorsdottir \& Wagner-Cremer 2019). A positive response of the vegetation such as earlier leaf-out and flowering dates is already evident in ground-based observational studies for individual species (Chmielewski \& Rotzer 2001; WagnerCremer et al. 2010; Weijers et al. 2017; Higgens et al. 2020) as well as from remote sensing studies on ecosystem level phenology (Xu et al. 2013; Hobbie et al. 2017; Berner et al. 2020). Still, earlier onset of the phenological cycle also poses threats to the vegetation through increased vulnerability to late frost events (Wipf et al. 2009; Weijers et al. 2018; Francon et al. 2020).

The driving mechanism behind the regional winter and spring weather conditions that regulate northern latitude plant phenology is the NAO (D'Odorico et al. 2002; Cook et al. 2005; Weijers et al. 2017). Being induced by SLP differences, the NAO determines wind speed and direction, seasonal heat, moisture transport, storm tracks, cloudiness and sea-ice cover through atmospheric mass balance shifts between the Arctic and the subtropical Atlantic (Hurrell et al. 2003; Young et al. 2012). Moreover, 
a strong correlation is known to exist between SLP and the prevailing surface air temperature in the adjacent terrestrial regions. The differences in SLP produce a typical, yet insufficiently understood, 'seesaw' pattern of warmer winter and spring temperatures over Scandinavia and cooler temperatures over Greenland during the positive phase of the NAO, and vice versa during its negative phase (van Loon \& Rogers 1978; Hurrell 1995; D'Odorico et al. 2002; Polyakov et al. 2003).

Plant responses are, thus, likely related to the annual intensity of this winter and spring weather-determining atmospheric circulation system. Implementing biological indicators, such as plant traits that capture seasonal temperatures, can resolve local to regional plant responses and, therefore, facilitate more accurate estimates of vegetation dynamics across the NAO-susceptible area. Many plant-biological indicators that are available in the Arctic, however, are predominantly sensitive to summer temperatures (Weijers et al. 2010; Park et al. 2019). The sparse information on broader seasonal temperature regimes is currently obtained through tree ring-width analyses indicative for winter/spring dynamics (Hollesen et al. 2015; Sakashita et al. 2018) or shoot-length analyses of the Arctic dwarf shrub Cassiope tetragona, which has been shown to capture GDD and Arctic Oscillation/NAO phase changes (Aanes et al. 2002; Welker et al. 2005; Weijers et al. 2013; Weijers et al. 2017).

A quantifiable imprint of GDD and spring onset date is observed in the microscopic leaf morphology of the common (sub-)Arctic shrub Betula nana (Wagner-Cremer et al. 2010; Steinthorsdottir \& Wagner-Cremer 2019; Ercan et al. 2021). Time-series analysis of annually collected leaf samples from northern Finland revealed a strong correlation between the UI and spring and summer temperatures, allowing for full maturation of leaves reaching maximum epidermal cell size during warm growing seasons, whereas cold growing seasons suppress the lateral epidermal cell expansion during the maturation process (Wagner-Cremer et al. 2010; Steinthorsdottir $\delta$ Wagner-Cremer 2019). The degree of cell maturation is thereby quantified as the UI, which is the ratio of CC over CA (Kürschner 1997; Wagner-Cremer et al. 2010). This stimulation of cell expansion under increasing GDD has been confirmed in a spatial analysis of Betula pubescens leaves sampled over a large latitudinal gradient with significant differences in growth period and temperature, following a similar trend (Ercan et al. 2020).

In the present study, we determined the UI of $B$. nana historical leaf samples from Disko Island, west Greenland, retrieved from the herbarium collections of the Arctic Station and Copenhagen University. The Greenlandic site results are compared to UI measurements on sub-fossil
B. nana leaves extracted from well-dated peat sections in Palomaa, northern Finland (Wagner-Cremer et al. 2010; Finsinger et al. 2013). The complementary localities provide leaf samples for the past 150 years and date back to the onset of anthropogenic warming (Fischer et al. 2018).

Based on these records, we made direct comparisons between the leaf epidermal cell UI and relevant NAO indices to test the influence of NAO-related thermal growing season variability on $B$. nana leaf properties. As UI captures the growing season thermal sum and is largely dependent on spring temperatures, we hypothesize that the UI records reflect the winter/early-spring NAO mode and intensity at both localities, that is, on Disko Island, west Greenland, and in northern Finland, in years with pronounced NAO expression.

\section{Materials and methods}

\section{Leaf samples}

Betula nana leaf specimens from the Disko area $\left(69^{\circ} 16^{\prime} \mathrm{N}\right.$ $53^{\circ} 27^{\prime} \mathrm{W}, 110 \mathrm{~m}$ a.s.l.; Fig. 1) were collected from the herbarium at Arctic Station, Qeqertarsuaq, and the Copenhagen Herbarium. From each preserved B. nana specimen, a minimum of five leaves were harvested. The oldest sample dates to 1865, whilst the most recent sample, from Disko, was sampled in Blæesedalen in 2017. The Disko data set consisted of a total of 29 samples spanning 152 years. Subfossil B. nana leaves were retrieved from a well-dated peat section from a bog in Palomaa, Finland $\left(69^{\circ} 15^{\prime} \mathrm{N}, 27^{\circ} 14^{\prime} \mathrm{E}, 179 \mathrm{~m}\right.$ a.s.l.; Fig. 1), yielding 36 samples for the 69-year period 1933-2002. The longer Palomaa time series data were cut-off at 1933 due to the increasing age-uncertainty in the older section of the peat core (Finsinger et al. 2013). The source material is shown in Fig. 2a, b.

From the Disko herbarium specimen, $0.5 \times 0.5 \mathrm{~cm} \mathrm{sec}-$ tions from the central part of individual leaves were bleached in sodium hypochlorite $(<5 \%)$ at room temperature for 12-24 hr. From each sample, three leaves were used. For each of the Palomaa samples, several leaf fragments of the same size $\left(\mathrm{l} \mathrm{cm}^{2}\right)$ were used (Finsinger et al. 2013).

The cuticle bearing epidermis was subsequently removed with tweezers and stained with safranin. Five digital photographs of each cuticle bearing epidermis peel were taken using a Leica (Wetzlar) Quantimet 500 $\mathrm{C} / 500+$ light microscope using the AnalySIS image analysis software (AnalySIS auto 5.1) at $1000 \times$ magnification. Examples of typical epidermal cell images are shown in Fig. 2c, d. Analyses of epidermal cell properties were performed using the Image 1.52 a software. 


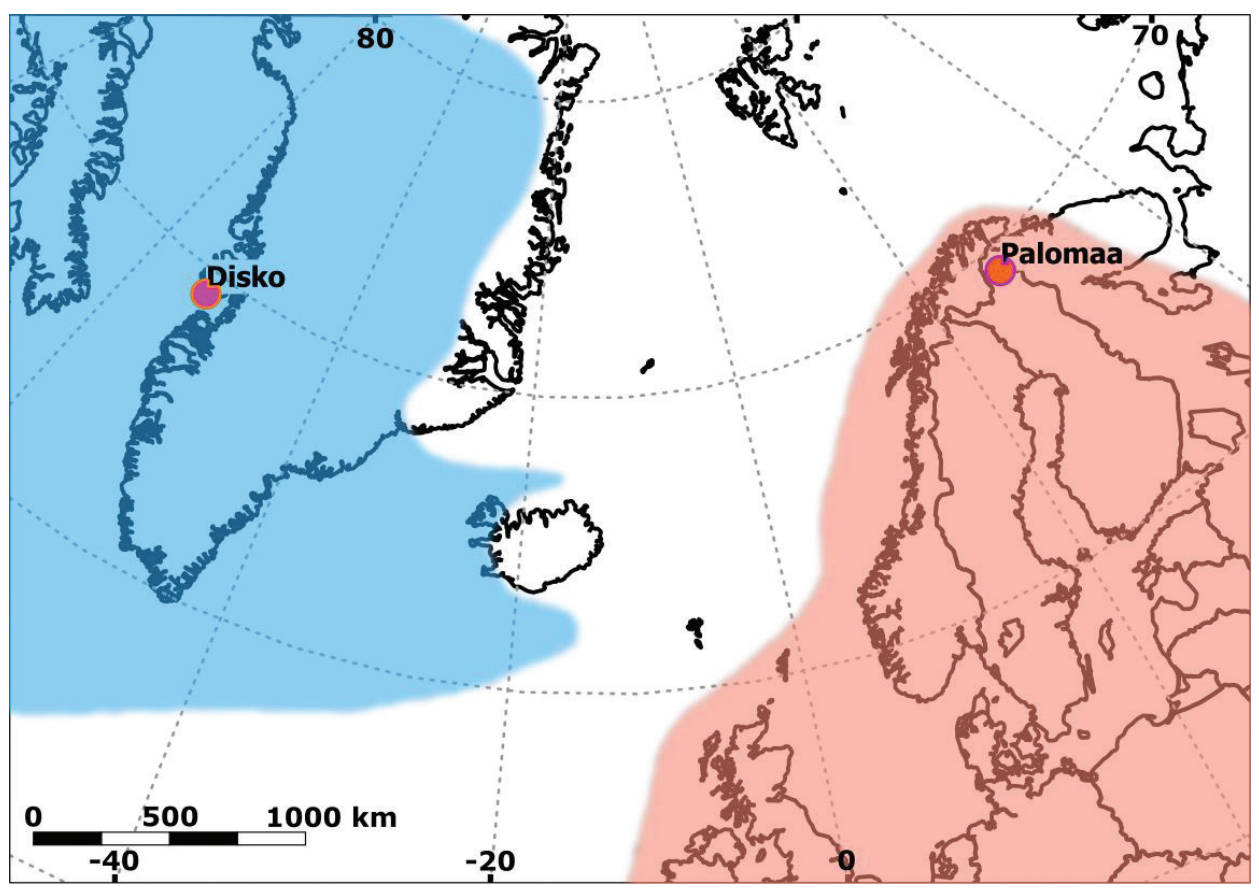

Fig. 1 Locations of the study sites, Disko Island, Greenland, and Palomaa, Finland, on a map of the north-east Atlantic region, indicating areas of positive (red shades) and negative (blue shades) correlation of local air temperature with the winter (DJF) NAO index (Hurrel 1995) values. The graphic is based on and adapted from Hanna \& Cropper (2017), Marcos et al. (2016) and Visbeck et al. (2001), compiled using the QGIS software, desktop version 3.14.15 (QGIS.org 2021), and a shape downloaded from http://tapiquen-sig.jimdofree.com (Carlos Efrain Porto Tapiquén. Geografía, SIG y Cartografía Digital, Valencia, Spain, 2020).



Fig. 2 (a) Part of the original peat core taken at Palomaa (30-60 cm depth); (b) representative Betula nana herbarium specimen from Disko Island; (c) microscopic image of a B. nana epidermal cells from Palomaa with high UI; (d) epidermal cell image with low UI typical for Greenland. The scale of (c) and (d) is the same. 


\section{Calculation of the UI}

To estimate the mean epidermal CA $\left(\mu \mathrm{m}^{2}\right)$ and epidermal CC $(\mu \mathrm{m}), 30$ random pavement cells per sample were analysed, avoiding cells over venation and leaf margins. From CA and CC, the UI (dimensionless) of the epidermal cell wall was calculated. UI indicates the relation between CC and CA, representing the sinuosity of the epidermis cell wall (Kürschner 1997):

$$
\mathrm{UI}[\text { dimensionless }]=\frac{\mathrm{CC}}{2 \pi \cdot \sqrt{\mathrm{CA} / \pi}}
$$

\section{Climate data}

To verify the reactiveness of local weather to NAO index fluctuations, temperature anomalies for the corresponding grid for each site were retrieved via the KNMI Climate Explorer (Trouet \& Van Oldenborgh 2013) from the gridded data set of the Berkeley Earth Surface Temperature Project (Rohde, Muller, Jacobsen, Muller et al. 2013; Rohde, Muller, Jacobsen, Perlmutter et al. 2013). For Disko, the $1^{\circ}$ grid formed by longitudes -54 to $-53^{\circ} \mathrm{E}$ and latitudes 69 to $70^{\circ} \mathrm{N}$ was used, and for Palomaa, the grid formed by longitudes 27 to $28{ }^{\circ} \mathrm{E}$ and latitudes 69 to 70 ${ }^{\circ} \mathrm{N}$. To compare the NAO index to the UI, two definitions of the NAO index were retrieved via the KNMI Climate Explorer. The first one (NAO-1) is defined as the difference in atmospheric pressure measured between Gibraltar (southernmost Iberia) and Stykkishólmur (Iceland) recorded from 1821 onwards, whilst the second one (NAO-2) represents the difference in atmospheric pressure measured between the Azores and Stykkishólmur, recorded from 1865 to 2002 (Jones et al. 1997). These two indices are strongly correlated $(r=0.78, p<0.001)$ and allow the expression of the NAO results using either of them with confidence.

From the temperature anomaly data and NAO index data, different subsets were isolated to capture dynamics from different parts of the year, potentially relevant for year-to-year differences in plant development. The monthly values were averaged for sets of several months that are indicative of the winter preceding the growing season (NDJF), late winter to early spring (FMA), the Arctic spring (AM) and the Arctic early summer (MJJ).

\section{Filter}

To prevent years with a weak temperature anomaly, NAO index or a too-low (immature) UI response from distorting the interpretation of the interactions between UI and NAO, a high-pass filter was used. The used cut-off value was one half of the standard deviation of the UI values (z-scored, to centre values around 0, for comparison with index values) and each of the temperature anomaly and NAO index values, both in the positive and negative directions. In some cases, NAO-1 was left in the selection where NAO-2 was cut off and vice versa, because either of the index values was not pronounced enough to be greater than the related filter value. This resulted in some instances, in which only one of the two index versions was represented in the comparisons. If no filter was used on the data for a specific correlation, it is explicitly mentioned below.

\section{Statistics}

All filtering, statistics and graph production were performed using the $R$ software, version 4.0 ( $\mathrm{R}$ Core Team 2020). Pearson's correlation tests were used to check for significant $(p<0.05)$ associations between subsets of the localized temperature anomalies and corresponding subsets of NAO signals, and between the corresponding subsets of NAO signals and z-scored UI data.

\section{Results}

Analysis of B. nana leaf material from Disko (1865-2017) and Palomaa (1933-2002) on UI yielded 29 data points for Disko and 35 for Palomaa (Fig. 3). The mean value of the Disko UI was 1.18 (min. 1.13, max. 1.21, $\sigma=0.2$ ), and 1.24 (min. 1.15, max. 1.34, $\sigma=0.04$ ) for Palomaa, indicating greater $B$. nana leaf cell expansion at the latter site. The overall range of the Palomaa UI values was higher, more variable and averaged above the mean UI measured on Disko leaf samples. The Disko data set showed a narrower range of UI values, with maximum values in the lower range of Palomaa UI values. A direct comparison between the UI records from Disko and Palomaa could not be made because of a lack of sufficient overlapping years.

In the comparison between the local temperature anomalies and NAO index data for the years for which we also have UI data, statistically significant correlations were found between most of the subsets (Table 1). From all the correlations between subsets of temperature anomalies from both locations with both NAO indices, all directions of correlations indicated a negative relation between the NAO and temperature on Disko and a positive relation between the NAO and temperature in Palomaa. The only non-significant relations found were those between NAO-2 ${ }_{\mathrm{MJJ}^{\prime}} \mathrm{NAO}-1_{\mathrm{AM}^{\prime}} \mathrm{NAO}-2_{\mathrm{AM}}$ and the corresponding temperature anomalies from Disko and the one between NAO- $1_{A M}$ and the corresponding temperature anomaly from Palomaa. 


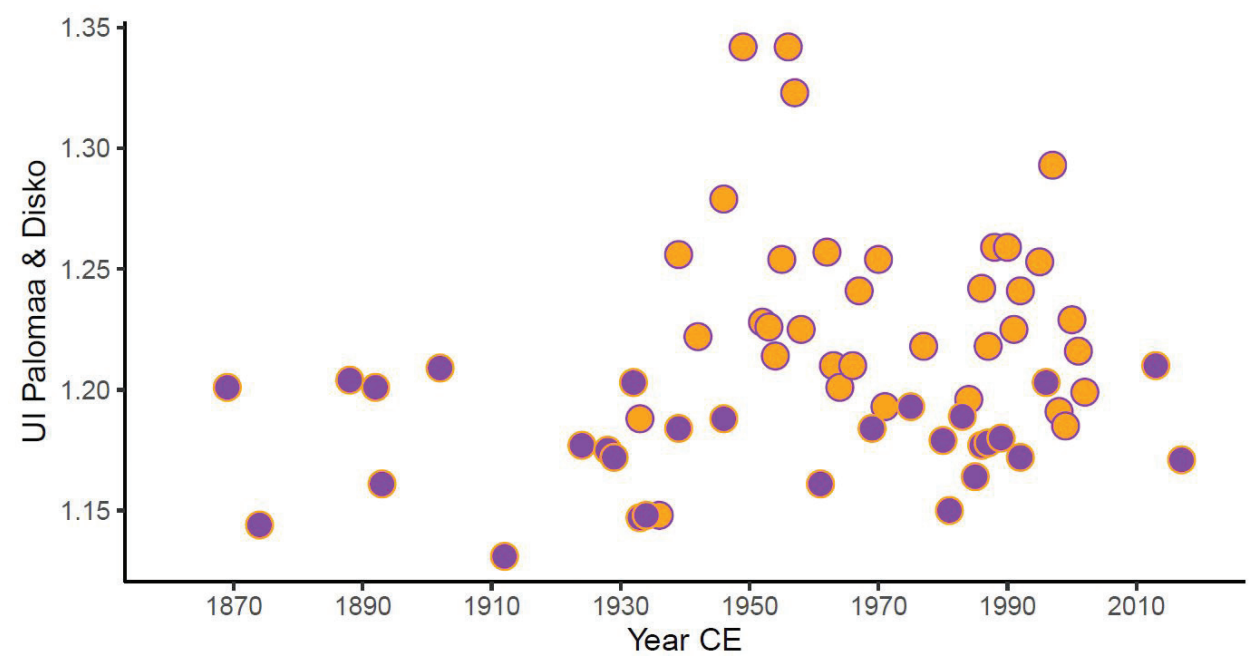

Fig. 3 Mean UI values for Betula nana herbarium samples from Disko (purple dots) and Palomaa (orange dots) for the individual years studied.

Table 1 Correlation coefficients $(r)$ between subsets of temperature anomaly values from Disko, Greenland, and Palomaa, Finland, against corresponding subsets of the NAO indices. All data are filtered with highpass criteria unless indicated.

\begin{tabular}{|c|c|c|}
\hline$r$ & $\begin{array}{c}\text { Temp. anomaly (subset) } \\
\text { Disko 1865-2017 (n) }\end{array}$ & $\begin{array}{l}\text { Temp. anomaly (subset) } \\
\text { Palomaa 1933-2002 (n) }\end{array}$ \\
\hline NAO- $1_{\text {no-filter }}$ & $-0.49^{\mathrm{a}}(148)$ & $+0.36^{\mathrm{a}}(175)$ \\
\hline NAO- $2_{\text {no-filter }}$ & $-0.44^{\mathrm{a}}(131)$ & $+0.55^{\mathrm{a}}(143)$ \\
\hline NAO- $1_{\mathrm{NDJF}}$ & $-0.35^{\mathrm{a}}(149)$ & $+0.40^{\mathrm{a}}(176)$ \\
\hline $\mathrm{NAO}-2_{\mathrm{NDJF}}$ & $-0.38^{\mathrm{a}}(132)$ & $+0.26^{\mathrm{a}}(143)$ \\
\hline NAO- $1_{F M A}$ & $-0.30^{\mathrm{a}}(149)$ & $+0.25^{\mathrm{a}}(176)$ \\
\hline $\mathrm{NAO}-2_{\mathrm{FMA}}$ & $-0.42^{a}(132)$ & $+0.39^{\mathrm{a}}(144)$ \\
\hline NAO- $1_{A M}$ & $-0.07^{b}(149)$ & $+0.11^{\mathrm{b}}(176)$ \\
\hline NAO-2 $2_{\text {AM }}$ & $-0.06^{b}(132)$ & $+0.19^{c}(144)$ \\
\hline NAO-1 ${ }_{\text {MJ }}$ & $-0.18^{\mathrm{c}}(149)$ & $+0.16^{c}(176)$ \\
\hline NAO- $2_{\text {MJ }}$ & $-0.06^{d}(132)$ & $+0.27^{d}(144)$ \\
\hline
\end{tabular}

${ }^{a} p \leq 0.001 ;{ }^{b} p>0.05 ;{ }^{c} p \leq 0.05 ;{ }^{d} p \leq 0.01$.

In a comparison between z-scored and filtered B. nana UI data from Disko (1865-2017) and Palomaa (1933-2002) and several subsets of filtered NAO- 1 and NAO-2 index values, the direction and relevance of deviation from the mean value were tested (Table 2). As the majority of UI datapoints from Disko are in antiphase with NAO, the correlation is negative in direction, whereas the majority of UI data points from Palomaa are in phase with the NAO indices, indicating an opposite response. Statistically significant correlations were determined for the subset average of the months FMA (NAO- $1_{\mathrm{FMA}}$ versus Disko UI: $r=-0.63, p \leq 0.05$; Fig. 4), AM (NAO-2 2 versus Disko UI: $r=-0.67, p \leq 0.05$ ) and for MJJ (NAO-2 $2_{\text {MJJ }}$ versus Disko UI: $r=-0.76, p \leq 0.05$; see Table 2 ). None of the Palomaa relations were significant. Figure 5
Table 2 Correlation coefficients ( $r$ ) between Betula nana UI values from Disko, Greenland, and Palomaa, Finland, against several subsets of the NAO indices. All data are filtered with high-pass criteria unless indicated.

\begin{tabular}{|c|c|c|}
\hline$r$ & UI Disko 1865-2017 (n) & UI Palomaa 1933-2002 (n) \\
\hline NAO- $1_{\text {no-filter }}$ & $-0.21^{\mathrm{a}}(29)$ & $+0.10^{\mathrm{a}}(42)$ \\
\hline NAO-2 ${ }_{\text {no-filter }}$ & $-0.32^{\mathrm{a}}(27)$ & $-0.04^{\mathrm{a}}(41)$ \\
\hline NAO- $1_{\text {NDJF }}$ & $-0.28^{\mathrm{a}}(10)$ & $+0.33^{\mathrm{a}}(10)$ \\
\hline $\mathrm{NAO}-2_{\mathrm{NDJF}}$ & $-0.16^{\mathrm{a}}(10)$ & $+0.12^{\mathrm{a}}(12)$ \\
\hline NAO- $1_{\text {FMA }}$ & $-0.63^{b}(12)$ & $+0.25^{\mathrm{a}}(12)$ \\
\hline $\mathrm{NAO}-2_{\mathrm{FMA}}$ & $-0.44^{a}(8)$ & $+0.21^{\mathrm{a}}(13)$ \\
\hline NAO- $1_{\text {AM }}$ & $-0.31^{\mathrm{a}}(10)$ & $+0.20^{\mathrm{a}}(14)$ \\
\hline NAO- $2_{\text {AM }}$ & $-0.67^{b}(13)$ & $-0.03^{\mathrm{a}}(10)$ \\
\hline NAO-1 ${ }_{\text {MJ }}$ & $+0.20^{\mathrm{a}}(11)$ & $+0.14^{\mathrm{a}}(10)$ \\
\hline $\mathrm{NAO}-2_{\text {мJ }}$ & $-0.76^{b}(10)$ & $-0.44^{a}(12)$ \\
\hline
\end{tabular}

${ }^{a} p>0.05 ;{ }^{b} p \leq 0.05$.

shows the interaction between $\mathrm{NAO}-\mathrm{I}_{\mathrm{NDJF}}$ and filtered z-scored Palomaa UI data, mostly in-phase with each other, though not significantly.

\section{Discussion}

The two UI data sets from the contrasting localities on Disko and in Palomaa revealed some differences. Whilst the UI values of Disko samples varied between 1.13 and 1.21, the Palomaa samples reached higher degrees of cell wall undulation with UI values up to 1.34, with only a few samples falling within the range of Disko UI levels (Fig. 3). The discrepancy between the overall ranges is related to the contrasting temperature regimes prevailing at the two sites. Annual temperature and GDD, quantifying the thermal sum during the growing season, at Disko are far lower than at Palomaa; the suboptimal growth conditions on Disko 


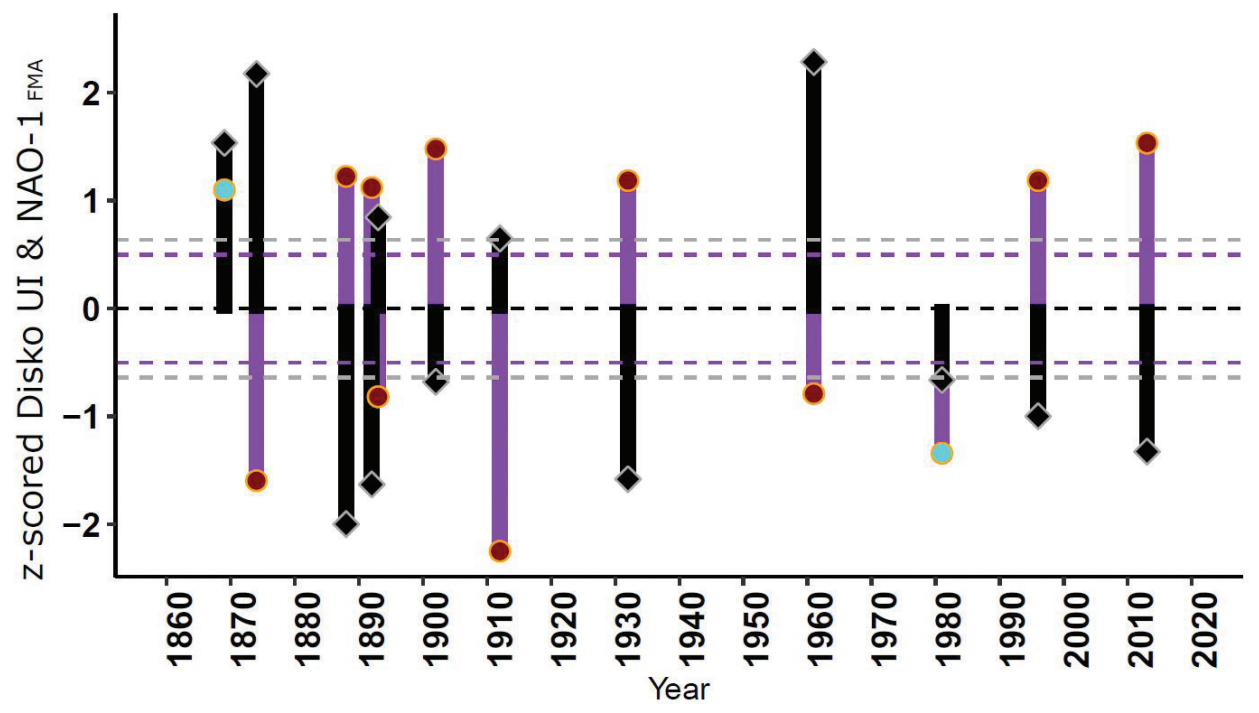

Fig. 4Z-scored UI data from Betula nana herbarium samples (dots) from Disko and NAO-1 ${ }_{\text {FMA }}$ index (black diamonds and bars) for each of the corresponding years (1865-2017). Blue UI dots indicate when UI follows NAO, and red dots indicate when they oppose in direction. Dotted lines indicate cut-off

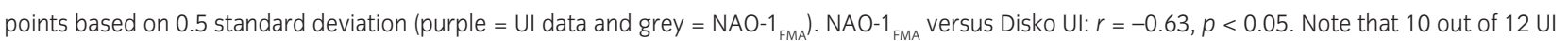
data points oppose the NAO in direction.

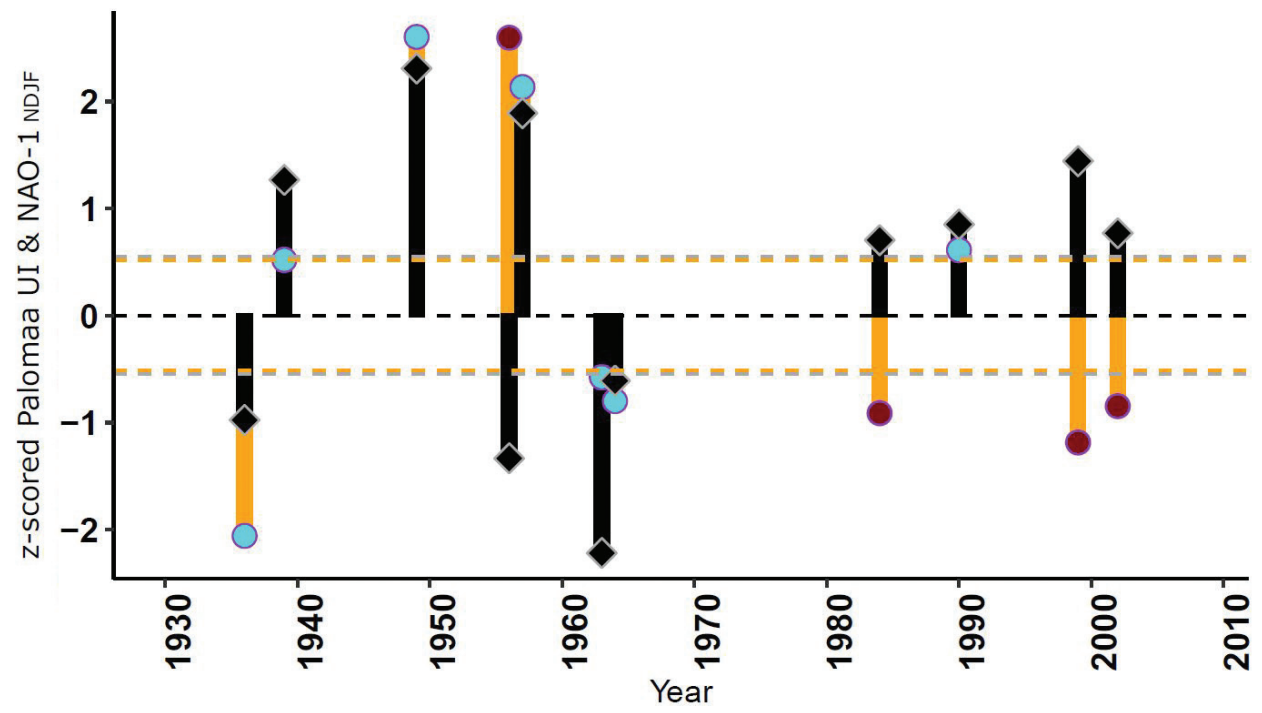

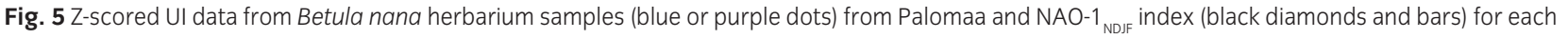
of the corresponding years (1933-2002). Blue UI dots indicate when UI follows NAO, and purple dots indicate when they oppose in direction. Dotted lines indicate cut-off points based on 0.5 standard deviation (orange $=\mathrm{UI}$ data and grey $=\mathrm{NAO}^{-1}{ }_{\text {NDJF }}$ ). NAO-1 ${ }_{\text {NDJF }}$ versus Palomaa UI: $r=0.33, p>0.05$. Note that seven out of $11 \mathrm{UI}$ data points follow the NAO in direction.

hamper leaf maturation (Wagner-Cremer et al. 2010). Palomaa, in contrast, is characterized by a more favourable climate for shrubs, enabling full leaf maturation (Finsinger et al. 2013). Generally, the climate of the Disko area is more oceanic, with relatively mild winters and cool summers, whilst the climate at Palomaa is more continental, with cold winters but warm summers.
Despite the general differences between the data from Palomaa and Disko presented here, both time series revealed systematic fluctuations related to the local growth conditions prevailing at the individual sites. Local temperature conditions during winter and the early growing season are closely linked to the prevailing SLP and the intensity of the NAO, which is quantified by indices based 
on SLP differences (Polyakov et al. 2003). A comparison of local temperature anomalies from the gridded Berkeley data set with corresponding subsets of the NAO indices (Table 1) confirmed the strong and significant relationship between local temperatures and the NAO, mainly in winter (NDJF and FMA). As the dominant factor for weather in the studied regions, the NAO also governs wind, humidity and cloudiness conditions (Hurrell et al. 2003; Young et al. 2012), thereby acting on adverse or beneficial weather traits, which can directly affect plant performance in terms of growth and development.

Most relations between Disko UI and NAO subsets were negative, whereas most relations between Palomaa UI and NAO subsets were positive (Table 2), in accordance with the seesaw characteristic of the NAO and its temperature influence. The most significant correlations were observed for the subset average of the months FMA with NAO-1 (Fig. 3), AM with NAO-2 and MJJ with NAO-2 (see Table 2). However, the MJJ correlation with Disko UI was ambiguous, as correlations with NAO- 1 and NAO-2 gave mixed results regarding the direction of the relation, although the unexpected positive correlation with NAO-1 was not significant. The winter and early growing seasons are important, as plant performance is very sensitive to late winter/early spring variability, especially in the Arctic (Li et al. 2016; Flynn \& Wolkovich 2018). Moreover, the NAO has its main influence on local weather conditions in winter/early spring (Hurrell 1995; Cook et al. 2002). Still, NAO has some influence on weather even during MJJ (Hurrell 1995), as is also evident in the correlations between local temperature anomalies and NAO indices (Table 1).

Although none of the Palomaa UI-NAO correlations were significant, most of the interactions between subsets were in-phase with NAO (see, for example, Fig. 5), agreeing with the expected influence of NAO in northern Finland. The low number of significant correlations between UI and NAO indices might be attributed to the low number of data points that passed the filter criteria, a result caused by the low number of total samples. Also, as the NAO has less influence in northern Finland (Uvo 2003), it might account for the lesser impact on UI there. Nevertheless, we found relevant and significant relations between Palomaa temperature anomalies and both NAO-1 and NAO-2. Although the indices quantify the NAO differently, they still represent the same meteorological phenomenon.

The UI, indicating different levels of maturity of the Disko samples, was more profoundly affected by NAO dynamics than the UI in Palomaa. This difference in the UI between NAO phases implies that the release of stress, for example, through higher late winter or early growing season temperatures, or other favourable weather conditions on Disko Island during a negative NAO phase, is beneficial for the maturation of $B$. nana leaves in this extreme environment. In contrast, a positive NAO phase and accompanying unfavourable weather conditions have an adverse effect on the UI. Under the overall more favourable growth conditions in Finland, which experiences much warmer growing seasons due to its continental climate, additional stress release during the early growing season produces a detectable signal in the leaf morphology, quantified as UI, whilst the final maturation of $B$. nana leaves is regulated through the length of the growing season by accumulating thermal sum totals (Wagner-Cremer et al. 2010; Steinthorsdottir \& Wagner-Cremer 2019). Despite the differences in signal intensity, our data show that the direction of response (positive or negative correlation) is likely opposite in the two contrasting sites, which is in line with the bipolar character of the NAO (van Loon \& Rogers 1978; Polyakov et al. 2003). The responsiveness of the UI of $B$. nana leaf remains from herbarium and subfossil records to alterations in the NAO suggests that this morphological trait is sensitive to this large-scale atmospheric system.

Effects of NAO dynamics on Arctic shrubs have also been observed for the circumarctic evergreen dwarf shrub Cassiope tetragona. Annual shoot increment of this species correlates with NAO driven temperature regimes (Rayback \& Henry 2006; Weijers et al. 2017). In Greenland, a significant negative correlation between shoot length indices and the NAO (June: $r=-0.39, p<$ 0.01 ; July: $r=-0.26, p<0.05$ ) occurs in Johannes $\mathrm{V}$. Jensen Land, the northernmost region of Greenland (Weijers et al. 2017). In the remote settings of this location, the cumulative warmth of the growing season is received in late June and July. However, the negative correlation with the October Arctic Oscillation index of the previous year suggests that winter conditions there also play a regulating role, potentially through sea-ice feedback and from the Ilullisat iceberg on summer temperatures (Wang \& Ikeda 2000; Koenigk et al. 2016; Weijers et al. 2017; Buchwal et al. 2020). The results of the present study provide more direct evidence for the relevance of weather conditions (Table 1) during winter and spring months for the growth of (sub-)Arctic shrubs such as B. nana (Table 2). Our findings support those of an earlier study of B. nana shrub ring-width in Disko, where time series analysis over the past century has shown that, besides GDD, winter and spring conditions play an important role for the growth performance of this species (Hollesen et al. 2015). Especially important for late winter and early spring, dynamics are the mechanics 
surrounding soil thaw, affecting water and nutrient access, enabling or impeding plant growth.

The addition of the UI to NAO-sensitive proxies is highly relevant for seasonal climate reconstructions, as the effect of combining several proxy data sets has the potential to improve NAO reconstructions (Schmutz et al. 2000). Combining non-instrumental-based proxies generally results in more robust reconstructions, and the best results are achieved by combining these with instrumental data (Cullen et al. 2001). Also, plant-based proxies for NAO signals may be more suitable than proxies for an individual climate parameter, since NAO incorporates multiple parameters such as temperature, precipitation and cloudiness-all potentially affecting plant performance-and therefore representing a more complete signal (Weijers et al. 2017). Accordingly, the reaction of UI to NAO, as a (micro-)morphological response to a largescale atmospheric climate system, is additional confirmation of the direct ecological importance of NAO fluctuations (Ottersen et al. 2001).

\section{Proxy relevance}

The UI was conceptually shown to be an NAO indicator in this study; it raises new opportunities in terms of further research on NAO spring dynamics through time, especially with the future availability of larger data sets. In the recent past, biological proxies in the Arctic and alpine tundra biome mainly revolved around dendrochronological shrub studies, but the UI can provide additional insight into NAO fluctuations in the NAOinfluenced areas beyond and above the treeline. This would mainly be the case in the (sub-)Arctic regions of Europe and North America, such as the areas where the leaf material studied in this research originated from. Also, when treelines shift through time as climate changes (Kruse et al. 2016), a tundra shrub-based proxy could aid in providing more continuous records. However, as the exact onset of the NAO is uncertain (Vinther et al. 2003), the UI proxy could still account for opposing or antiphase signals from both sides of the Atlantic. This additional potential for reconstruction will allow for increased cross-validation between areas for which previously no proxy NAO records exist and for areas with known proxy NAO records. In particular, this enables NAO reconstructions that exceed current meteorological records. The addition of the spring-sensitive UI proxy to NAO-related discussions, such as episodes of historical climatic changes like the Medieval Warm Period or the transition into the Little Ice Age, would be very welcome as these events have been suggested to be related to NAO phase changes (Young et al. 2015).

\section{Conclusions}

The opposite responses of UI in Finland and Greenland support our main hypothesis that lateral epidermal cell expansion in B. nana leaves depends in part on NAOdetermined winter and spring meteorological conditions, although the findings from Finland did not prove to be significant. Additionally, our results suggest that the characteristic 'seesaw' relation between the opposing extreme ends in the NAO susceptible region is directly reflected in plant growth. During winter (NDJF) and late winter/ early spring (FMA), the UI from Palomaa, Finland, reacted positively to a positive NAO phase, whilst the UI from Disko, Greenland, reacted negatively and vice versa. This suggests that the NAO impacts local plant performance in terms of leaf development, as imprinted in the UI, according to the characteristic NAO seesaw pattern prevalent in the Northern Atlantic region. The use of the UI derived from herbaria and natural archives such as peat bogs and lake sediments as NAO proxies may improve our understanding of NAO dynamics over the past centuries and help to quantify the future impact of the NAO on plant performance and ecology.

\section{Acknowledgements}

The authors greatly appreciate the friendly support and permission to sample leaf specimens received from the Arctic Station herbarium (Qeqertarsuaq, Greenland) and the Herbarium C (Natural History Museum of Denmark).

\section{Disclosure statement}

The authors report no conflict of interest.

\section{Funding}

This study was financially supported by the Dutch Research Council for the project Growing Season Changes in the High Northern Latitudes during the last Millennium (grant no. ALWOP.2015.110).

\section{References}

Aanes R., Sæther B.-E., Smith F.M., Cooper E.J., Wookey P.A. \& Øritsland N.A. 2002. The Arctic Oscillation predicts effects of climate change in two trophic levels in a High-Arctic ecosystem. Ecology Letters 5, 445-453, doi: 10.1046/j.1461-0248.2002.00340.x.

Berner L.T., Massey R., Jantz P., Forbes B.C., Macias-Fauria M., Myers-Smith I., Kumpula T., Gauthier G., AndreuHayles L., Gaglioti B.V., Burns P., Zetterberg P., D'Arrigo R. 
\& Goetz S.J. 2020. Summer warming explains widespread but not uniform greening in the Arctic tundra biome. Nature Communications 11, article no. 4621, doi: 10.1038/ s41467-020-18479-5.

Bintanja R., van der Wiel K., Linden E.C., van der Reusen J., Bogerd L., Krikken F. \& Selten F.M. 2020. Strong future increases in Arctic precipitation variability linked to poleward moisture transport. Science Advances 6, eaax6869, doi: 10.1126/sciadv.aax6869.

Box J.E., Colgan W.T., Christensen T.R., Schmidt N.M., Lund M., Parmentier F.J.W., Brown R., Bhatt U.S., Euskirchen E.S., Romanovsky, V.E., Walsh J.E., Overland J.E., Wang M., Corell R.W., Meier W.N., Wouters B., Mernild S., Mård J., Pawlak J. \& Olsen M.S. 2019. Key indicators of Arctic climate change: 1971-2017. Environmental Research Letters 14, article no. 045010, doi: 10.1088/1748-9326/aafclb.

Buchwal A., Sullivan P.F., Macias-Fauria M., Post E., MyersSmith I.H., Stroeve J.C., Blok D., Tape K.D., Forbes B.C., Ropars P., Lévesque E., Elberling B., Angers-Blondin S., Boyle J.S., Boudreau S., Boulanger-Lapointe N., Gamm C., Hallinger M., Rachlewicz G., Young A., Zetterberg P. \& Welker J.M. 2020. Divergence of Arctic shrub growth associated with sea ice decline. Proceedings of the National Academy of Sciences 117, 33334-33344, doi: 10.1073/pnas.2013311117.

Chmielewski F.M. \& Rotzer T. 2001. Response of tree phenology to climate change across Europe. Agricultural and Forest Meteorology 108, 101-112, doi: 10.1016/ S0168-1923(01)00233-7.

Cook B.I., Smith T.M. \& Mann M.E. 2005. The North Atlantic Oscillation and regional phenology prediction over Europe. Global Change Biology 11, 919-926, doi: 10.1111/j.1365-2486.2005.00960.x.

Cook E.R., D'Arrigo R.D. \& Mann M.E. 2002. A well-verified, multiproxy reconstruction of the winter North Atlantic Oscillation index since A.D. 1400. Journal of Climate 15, 1754-1764, doi: 10.1175/1520-0 442(2002)015<1754:AWVMRO>2.0.CO;2.

Cullen H.M., D’Arrigo R.D., Cook E.R. \& Mann M.E. 2001. Multiproxy reconstructions of the North Atlantic Oscillation. Paleoceanography 16, 27-39, doi: 10.1029/1999PA000434.

D'Odorico P., Yoo J.C. \& Jaeger S. 2002. Changing seasons: an effect of the North Atlantic Oscillation? Journal of Climate 15, 435-445, doi: 10.1175/1520-0442(2002)015<0435:CSAEOT>2.0.CO;2.

Ercan F.E.Z., De Boer H.J. \& Wagner-Cremer F. 2020. A growing degree day inference model based on mountain birch leaf cuticle analysis over a latitudinal gradient in Fennoscandia. Holocene 30, 344-349, doi: 10.1177/0959683619865605.

Ercan F.E.Z., Mikola J., Silfver T., Myller K., Vainio E., Słowińska S., Słowiński M., Lamentowicz M., Blok D. \& Wagner-Cremer F. 2021. Effects of experimental warming on Betula nana epidermal cell growth tested over its maximum climatological growth range. PLoS One 16, e0251625, doi: 10.1371/journal.pone.0251625.

Finsinger W., Schoning K., Hicks S., Lücke A., Goslar T., Wagner-Cremer F. \& Hyyppä H. 2013. Climate change during the past 1000 years: a high-temporal-resolution multiproxy record from a mire in northern Finland. Journal of Quaternary Science 28, 152-164, doi: 10.1002/jqs.2598.

Fischer H., Meissner K.J., Mix A.C., Abram N.J., Austermann J., Brovkin V., Capron E., Colombaroli D., Daniau A., Dyez K.A., Felis T., Finkelstein S.A., Jaccard S.L., McClymont E.L., Rovere A., Sutter J., Wolff E.W., Affolter S., Bakker P. \& Zhou L. 2018. Palaeoclimate constraints on the impact of $2{ }^{\circ} \mathrm{C}$ anthropogenic warming and beyond. Nature Geoscience 11, 474-485, doi: 10.1038/s41561-018-0146-0.

Flynn D.F.B. \& Wolkovich E.M. 2018. Temperature and photoperiod drive spring phenology across all species in a temperate forest community. New Phytologist 219, 1353-1362, doi: $10.1111 / \mathrm{nph} .15232$.

Francon L., Corona C., Till-Bottraud I., Choler P., Carlson B.Z., Charrier G., Améglio T., Morin S., Eckert N., Roussel E., Lopez-Saez J. \& Stoffel M. 2020. Assessing the effects of earlier snow melt-out on alpine shrub growth: the sooner the better? Ecological Indicators 115, article no. 106455, doi: 10.1016/j.ecolind.2020.106455.

Hanna E. \& Cropper T.E. 2017. North Atlantic Oscillation. Oxford Research Encyclopedia of Climate Science 27, 536-539, doi: 10.1093/acrefore/9780190228620.013.22.

Higgens R.F., Pries C.H. \& Virginia R.A. 2020. Trade-offs between wood and leaf production in Arctic shrubs along a temperature and moisture gradient in west Greenland. Ecosystems 24, 652-666, doi: 10.1007/s10021-020-00541-4.

Hobbie J.E., Shaver G.R., Rastetter E.B., Cherry J.E., Goetz S.J., Guay K.C., Gould W.A. \& Kling G.W. 2017. Ecosystem responses to climate change at a Low Arctic and a High Arctic long-term research site. Ambio 46, 160-173, doi: 10.1007/s13280-016-0870-x.

Hollesen J., Buchwal A., Rachlewicz G., Hansen B.U., Hansen M.O., Stecher O. \& Elberling, B. 2015. Winter warming as an important co-driver for Betula nana growth in western Greenland during the past century. Global Change Biology 21, 2410-2423, doi: 10.1111/gcb.12913.

Hurrell J.W. 1995. Decadal trends in the North Atlantic Oscillation: regional temperatures and precipitation. Science 269, 676-679, doi: 10.1126/science.269.5224.676.

Hurrell J.W., Kushnir Y., Ottersen G. \& Visbeck, M. 2003. An overview of the North Atlantic Oscillation. Geophysical Monograph Series 134, 1-35, doi: 10.1029/134GM01.

Jones P.D., Jonsson T. \& Wheeler D. 1997. Extension to the North Atlantic Oscillation using early instrumental pressure observations from Gibraltar and south-west Iceland. International Journal of Climatology 17, 1433-1450, doi: 10.1002/(sici) 1097-0088(19971115)17:13<1433::aidjoc203>3.3.co;2-g.

Koenigk T., Caian M., Nikulin G. \& Schimanke S. 2016. Regional Arctic sea ice variations as predictor for winter climate conditions. Climate Dynamics 46, 317-337, doi: 10.1007/s00382-015-2586-1.

Kruse S., Wieczorek M., Jeltsch F. \& Herzschuh U. 2016. Treeline dynamics in Siberia under changing climates as inferred from an individual-based model for Larix. Ecological Modelling 338, 101-121, doi: 10.1016/j. ecolmodel.2016.08.003. 
Kürschner W.M. 1997. The anatomical diversity of recent and fossil leaves of the durmast oak (Quercus petraea Lieblein/Q. pseudocastanea Goeppert)—implications for their use as biosensors of paleoatmospheric $\mathrm{CO}_{2}$ levels. Review of Palaeobotany and Palynology 96, 1-30, doi: 10.1016/S0034-6667(96)00051-6.

Li J., Fan K. \& Xu Z. 2016. Links between the late wintertime North Atlantic Oscillation and springtime vegetation growth over Eurasia. Climate Dynamics 46, 987-1000, doi: 10.1007/s00382-015-2627-9.

Marcos R., Torralba V., Cortesi N., González N., Soret A. \& Doblas-Reyes F.J. 2016. Characterization of near surface wind speed and temperature statistical distributions. Earth Sciences Technical Report BSC-ESS-2016-006. Barcelona: Barcelona Supercomputing Center.

Meredith M., Sommerkorn M., Cassotta S., Derksen C., Ekaykin A., Hollowed A., Kofinas G., Mackintosh A., Melbourne-Thomas J., Muelbert M.M.C., Ottersen G., Pritchard H. \& Schuur E.A.G. 2019. Polar regions. In H.-O. Pörtner et al. (eds.): IPCC special report on the ocean and cryosphere in a changing climate. Accessed on the internet at https://www.ipcc.ch/site/assets/uploads/ sites/3/2019/11/07_SROCC_Ch03_FINAL.pdf on 12 November 2021.

Ottersen G., Planque B., Belgrano A., Post E., Reid P.C. \& Stenseth N.C. 2001. Ecological effects of the North Atlantic Oscillation. Oecologia 128, 1-14, doi: 10.1007/ s004420100655.

Park H.S., Kim S.J., Stewart A.L., Son S.W. \& Seo K.H. 2019. Mid-Holocene Northern Hemisphere warming driven by Arctic amplification. Science Advances 5, eaax8203, doi: 10.1126/sciadv.aax8203.

Polyakov I.V., Bekryaev R.V., Alekseev G.V., Bhatt U.S., Colony R.L., Johnson M.A., Maskshtas A.P. \& Walsh, D. 2003. Variability and trends of air temperature and pressure in the maritime Arctic, 1875-2000. Journal of Climate 16, 2067-2077, doi: 10.1175/1520-0442(2003)016<2067:VAT OAT>2.0.CO;2.

QGIS.org 2021. QGIS Geographic Information System. QGIS Association. Accessed on the internet at https://www.qgis. org on 19 January 2021.

R Core Team 2020. R: a language and environment for statistical computing. Vienna: R Foundation for Statistical Computing.

Rayback S.A. \& Henry G.H.R. 2006. Reconstruction of summer temperature for a Canadian High Arctic site from retrospective analysis of the dwarf shrub, Cassiope tetragona. Arctic, Antarctic, and Alpine Research 38, 228-238, doi: 10.1657/1523-0430(2006)38[228:ROSTFA]2.0.CO;2.

Rohde R., Muller R.A., Jacobsen R., Muller E. \& Wickham C. 2013. A new estimate of the average Earth surface land temperature spanning 1753 to 2011. Geoinformatics $\theta$ Geostatistics: An Overview 1(1), doi: 10.4172/2327-4581.1000101

Rohde R., Muller R., Jacobsen R., Perlmutter S. \& Mosher S. 2013. Berkeley Earth temperature averaging process. Geoinformatics $\theta$ Geostatistics: An Overview 01(02), doi: 10.4172/2327-4581.1000103.
Sakashita W., Yokoyama Y., Miyahara H., Aze T., Obrochta S.P., Ohyama M. \& Yonenobu H. 2018. Assessment of northeastern Japan tree-ring oxygen isotopes for reconstructing early summer hydroclimate and spring Arctic Oscillation. Geochemistry, Geophysics, Geosystems 19, 35203528, doi: 10.1029/2018GC007634.

Schmutz C., Luterbacher J., Gyalistras D., Xoplaki E. \& Wanner H. 2000. Can we trust proxy-based NAO index reconstructions? Geophysical Research Letters 27, 1135-1138, doi: 10.1029/1999GL011045.

Steinthorsdottir M. \& Wagner-Cremer F. 2019. Hot summers ahead? Multi-decadal spring season warming precedes sudden summer temperature rise in pre-anthropogenic climate change summer temperature rise in pre-anthropogenic climate change. GFF 141, 175-180, doi: 10.1080/11035897.2019.1655791.

Trouet V. \& Van Oldenborgh G.J. 2013. KNMI Climate Explorer: a web-based research tool for high-resolution paleoclimatology. Tree-Ring Research 69, 3-13, doi: 10.3959/1536-1098-69.1.3.

Uvo C.B. 2003. Analysis and regionalization of northern European winter precipitation based on its relationship with the North Atlantic Oscillation. International Journal of Climatology 23, 1185-1194, doi: 10.1002/joc.930.

van Loon H. \& Rogers, J.C. 1978. The seesaw in winter temperatures between Greenland and northern Europe. Part I: general description. Monthly Weather Review 106, 296-310, doi: 10.1175/1520-0493(1978) 106<0296:TSIWTB>2.0.CO;2.

Vinther B.M., Johnsen S.J., Andersen K.K., Clausen H.B. \& Hansen A.W. 2003. NAO signal recorded in the stable isotopes of Greenland ice cores. Geophysical Research Letters 30, article no. 1387, doi: 10.1029/2002GL016193.

Visbeck M.H., Hurrell J.W., Polvani L. \& Cullen H.M. 2001. The North Atlantic Oscillation: past, present, and future. Proceedings of the National Academy of Sciences of the United States of America 98, 12876-12877, doi: 10.1073/ pnas.231391598

Wagner-Cremer F., Finsinger W. \& Moberg A. 2010. Tracing growing degree-day changes in the cuticle morphology of Betula nana leaves: a new micro-phenological palaeoproxy. Journal of Quaternary Science 25, 1008-1017, doi: 10.1002 /jqs. 1388 .

Walker D.A., Raynolds M.K., Daniëls F.J., Einarsson E., Elvebakk A. \& Gould W.A. 2005. The circumpolar Arctic vegetation map. Journal of Vegetation Science 16, 267-282, doi: $\quad 10.1658 / 1100-9233(2005) 016[0267: T C A V M] 2.0$ .CO; 2 .

Wang J. \& Ikeda M. 2000. Arctic Oscillation and Arctic SeaIce Oscillation. Geophysical Research Letters 27, 1287-1290, doi: 10.1029/1999GL002389.

Weijers S., Beckers N. \& Löffler J. 2018. Recent spring warming limits near-treeline deciduous and evergreen alpine dwarf shrub growth. Ecosphere 9, e02328, doi: 10.1002/ ecs2.2328

Weijers S., Broekman R. \& Rozema J. 2010 . Dendrochronology in the High Arctic: July air temperatures reconstructed from annual shoot length growth of the circumarctic 
dwarf shrub Cassiope tetragona. Quaternary Science Reviews 29, 3831-3842, doi: 10.1016/j.quascirev.2010.09.003.

Weijers S., Buchwal A., Blok D., Löffler J. \& Elberling B. 2017. High Arctic summer warming tracked by increased Cassiope tetragona growth in the world's northernmost polar desert. Global Change Biology 23, 5006-5020, doi: $10.1111 /$ gcb.13747.

Weijers S., Wagner-Cremer F., Sass-Klaassen U., Broekman R. \& Rozema J. 2013. Reconstructing High Arctic growing season intensity from shoot length growth of a dwarf shrub. The Holocene 23, 721-731, doi: $10.1177 / 0959683612470178$.

Welker J.M., Rayback S. \& Henry G.H.R. 2005. Arctic and North Atlantic Oscillation phase changes are recorded in the isotopes $\left(\delta^{18} \mathrm{O}\right.$ and $\left.\delta^{13} \mathrm{C}\right)$ of Cassiope tetragona plants. Global Change Biology 11, 997-1002, doi: 10.1111/j.1365-2486.2005.00961.x.

Wipf S., Stoeckli V. \& Bebi P. 2009. Winter climate change in alpine tundra: plant responses to changes in snow depth and snowmelt timing. Climatic Change 94, 105-121, doi: 10.1007/s10584-009-9546-x.

Xu L., Myneni R.B., Chapin F.S. III, Callaghan T.V., Pinzon J.E., Tucker C.J., Zhu Z., Bi J., Ciais P., Tømmervik H., Euskirchen E.S., Forbes B.C., Piao S. L., Anderson B.T., Ganguly S., Nemani R.R., Goetz S.J., Beck P.S. Bunn A.G. \& Stroeve J.C. 2013. Temperature and vegetation seasonality diminishment over northern lands. Nature Climate Change 3, 581-586, doi: 10.1038/nclimate1836.

Young G.H.F., McCarroll D., Loader N.J., Gagen M.H., Kirchhefer A.J. \& Demmler J.C. 2012. Changes in atmospheric circulation and the Arctic Oscillation preserved within a millennial length reconstruction of summer cloud cover from northern Fennoscandia. Climate Dynamics 39, 495-507, doi: 10.1007/s00382-011-1246-3.

Young N.E., Schweinsberg A.D., Briner J.P. \& Schaefer J.M. 2015. Glacier maxima in Baffin Bay during the Medieval Warm Period coeval with Norse settlement. Science Advances 1, el500806, doi: 10.1126/sciadv.1500806. 